\title{
Світлана Резнік
}

кандидат педагогічних наук, доцент, кафедра педагогіки і психології управління соціальними системами ім. академіка I.А. Зязюна, Національний технічний університет "Харківський політехнічний інститут"; Харків, Україна

ORCID: 0000-0001-8310-1242

E-mail:svreznik@i.ua

\section{СОЦІОКУЛЬТУРНІ ДЕТЕРМІНАНТИ РОЗВИТКУ ОСВІТИ ТА ВИКЛАДАЦЬ- КОЇ МАЙСТЕРНОСТІ У СТАРОДАВНІЙ ГРЕЦІЇ}

\begin{abstract}
Анотація: Розглянуто систему освіти Стародавньої Греції, щзо передбачала початкову, середню та вищу освіту, остання була представлена такими освітніми інститутами, як ефебії, софістичні, риторичні та філософські школи. 3 'ясовано, шьо викладацька майстерність була низькою для елементарної освіти, але на рівні вищоїактивно розвивалася як викладачька практика, так $і$ педагогічна теорія. Визначено, щзо зовнішніми чинниками розвитку освіти та викладацької майстерності у Стародавній Греції є техніко-економічний прогрес та політична експансія, демократична форма правління, уклад жсиття, який вимагав різносторонньої освіченості. Внутрішніми (норми та иінності): гомеровський епос як етичний ідеал, щчо «виховав Грецію», культура закритого чоловічого клубу, поширеність особистісних свобод, агоністичний дух суспільства, культ успіху та слави, розвиток раціонального мислення та науки, розповсюдженість переконання про иуінність освіти, ідеал різносторонньо освіченої особистості.
\end{abstract}

Ключові слова: соціокультурні детермінанти, розвиток освіти, викладацька майстерність, Стародавня Греція, освіта у Стародавній Грейіі.

\section{Svitlana Reznik}

$\mathrm{PhD}$ in Pedagogy, Associate Professor of the Department of pedagogy and psychology of social systems management, National technical University «Kharkiv polytechnic institute»; Kharkiv, Ukraine E-mail:svreznik@i.ua

\section{SOCIO-CULTURAL DETERMINANTS OF THE DEVELOPMENT OF EDUCATION AND TEACHING MASTERY IN ANCIENT GREECE}

\begin{abstract}
The education system of ancient Greece provided for primary, secondary and higher education, the latter was represented by such educational institutions as ephebic, sophistic, rhetorical and philosophical schools. Teaching skills were low for elementary education, but at the level of higher education, both teaching practice and pedagogical theory. The outer components of education and teaching skills development in Ancient Greece were technic-and-economic progress and political expansion, democratic form of government, and a way of life that demanded all-sided education. The inner factors (norms and values) were Homerus' epos as ethical ideal that "educated Greece", the culture of men's closed society,
\end{abstract}

(C) Світлана Резнік, 2019 
widely spread personal freedoms, agonistic spirit of society, success and glory cult, development of rational thinking and science, the widely spread belief in value of education, the ideal of a well-educated person.

Key words: socio-cultural determinants, education development, teaching skills, Ancient Greece, education in Ancient Greece.

\title{
Светлана Резник
}

\section{СОЦИОКУЛЬТУРНЫЕ ДЕТЕРМИНАНТЫ РАЗВИТИЯ ОБРАЗОВАНИЯ И ПРЕПОДАВАТЕЛЬСКОГО МАСТЕРСТВА В ДРЕВНЕЙ ГРЕЦИИ}

\begin{abstract}
Аннотация: Система образования Древней Греции предусматривала начальное, среднее и высшее образование, последняя была представлена такими образовательными институтами, как эфебии, софистические, риторические и философские школьы. Преподавательское мастерство было низким для элементарного образования, но на уровне высшего - активно развивается как преподавательская практика, так и педагогическая теория. Внешними факторами развития образования и преподавательского мастерства в Древней Греции являются технико-экономический прогресс и политическая экспансия, демократическая форма правления, уклад жизни, который требовал разносторонней образованности. Внутренними (нормы и иенности) - гомеровской эпос как этический идеал, который «воспитал Грецию», культура закрытого мужского клуба, распространенность личностных свобод, агонистический дух общества, культ успеха и славы, развитие рачионального мышления и науки, распространенность убеждения о иенности образования, идеал разносторонне образованной личности.
\end{abstract}

Ключевые слова: сочиокультурные детерминанты, развитие образования, преподавательское мастерство, Древняя Греция, образование в Древней Греиии.

\section{Svitlana Reznik}

An extended abstract of paper on the subject of:

"Socio-cultural determinants of the developments of education and the teaching mastery in ancient Greece"

Problem setting. The analysis of socio-cultural factors that determine education formation in different historic epochs is a topical problem of pedagogic science. First$l y$, this enables a deeper understanding of the moving forces in education development, its tendencies, and peculiarities, and secondly, to establish the factors that determine the periods of abrupt creative thrive of science and education.

Recent research and publication analysis. In historic retrospective, the problems of determining the factors of the thrive of culture and "the Greek miracle" in Antiquity times remain controversial in the works by philosophers, science historians, Antiquity specialists. In pedagogy works, the problem of analysis of socio-cultural determinants in education development in Ancient Greece is researched insufficiently.

Paper objective. Is to establish sociocultural factors that determined development of education and teaching skills in Ancient Greece.

Main material exposition. The education system that formed in Ancient Greece around the $V$ century $B C$ and existed several centuries included the stages that nowadays would be identified as primary, secondary, and higher education. Teaching skills at the higher education level was much more developed than at the elementary school. Com- 
petition for alumni, and "personality power", and intellectual prowess of Greek higher schools teachers were a "locomotive» of teaching skills' development.

The author analyzes the outer and inner factors of education's forming and development. Technic-and-economic expansion along with political expansion (VIII - VI centuries BC) enhanced personality activeness and initiative, intellectual development, they called for population's new knowledge. Realization of a person's right for participating in state activities under democratic form of government called for a person's being skilled in rhetoric, ability to argumentate, and convince. An atmosphere of discussion, argument, public defense of one's thought, struggling one's opponent created a special intellectual state of mind that enhanced emergence of outstanding thinkers, education system's evolvement, and general literacy of the population. The way of life itself called for education and knowledge of Greek polices citizens and simultaneously facilitated their formation through feasts, religious rites, sports competitions. The general atmosphere characteristic of cultural revolution influenced the population of Greek polices in a development-augmenting fashion.

Homer's epos became an ethical ideal for Hellada: the wish to be the first, the best, outstanding, insurmountable, a real hero, the tendency for competition and thirst for victory in competitions are the values and ideals that distinguish the characters of Homer's poems, which became a guiding principle for Greeks. From the culture of the men's closed club is derived both the attitude to knowledge passage at philosophy schools as a secrecy wherein only the chosen could be vested, and treating a teacher with particular and devotion. Uncommon for traditions of ancient times were personality freedoms as a characteristic peculiarity of Ancient Greece only, and the atmosphere of personality freedoms stipulate the freedom of thought, self-expression, and that of a person's abilities development.

An especially striking difference of Greek polices was the thirst for competition, agonistic spirit of Greek culture and the cult of glory and success. Traditions of permanent competition, influencing education's development, were double in character: on the one hand, to participate in them one had to have a corresponding training and to develop one's talents; secondly, competitions were organized at all education levels, starting with primary schools, so they can be viewed as a stimulating factor and teaching method.

One of the most important factors of Ancient Greece education forming is the development of national thinking and science, spreading of belief in value of education, an ideal of a widely educated person. The ideal

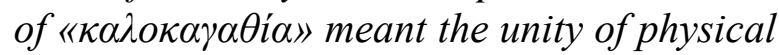
beauty and moral purity and was considered to be the main goal of education as something to be aspired for by every person.

Conclusions of the research. The education system of Ancient Greece supposed primary, secondary, and higher education, the latter being represented by such education institutions as euphibias, sophistic, rhetoric, and philosophic schools. Teaching skills were low for elementary education, but at the higher education level there were actively developing both teaching practice and pedagogic theory. The outer components of education and teaching skills development in Ancient Greece were technic-and-economic progress and political expansion, democratic form of government, and a way of life that demanded all-sided education. The inner factors (norms and values) were Homerus' epos as ethical ideal that "educated Greece», the culture of men's closed society, widely spread personal freedoms, agonistic spirit of society, success and glory cult, development of rational thinking and science, the widely spread belief in value of education, the ideal of a well-educated person. 
Постановка проблеми у загальному вигляді. Аналіз соціокультурних факторів, що визначають становлення освіти в різні історичні епохи, є актуальною проблемою педагогічної науки. Поперше, це дозволяє глибше осмислити рушійні сили розвитку освіти, його тенденції та особливості, а, по-друге, визначити чинники, які зумовлюють періоди бурхливого творчого розквіту освіти та науки.

Аналіз останніх досліджень і публікацій, у яких започатковано розв'язання даної проблеми і на які спирається автор. Розвиток сучасної української освіти та чинники, що його обумовлюють, аналізуються С.У. Гончаренком, I.А. Зязюном, Н.Г. Ничкало, В.В. Олійником, С.О. Сисоєвою, О.Г. Романовським, Л.Л. Товажнянським та ін. В історичній ретроспективі дискусійними лишаються проблеми визначення факторів розквіту культури та «грецького дива» в Антично- сті в працях філософів, істориків науки, антикознавців.

Виділення не вирішених раніше частин загальної проблеми, котрим присвячується дана стаття. У педагогічних роботах недостатньо дослідженою лишається проблема аналізу соціокультурних детермінант розвитку освіти у Стародавній Греції.

Формулювання цілей статті (постановка завдання). Стаття передбачає визначення соціокультурних факторів, що зумовили розвиток освіти та викладацької майстерності у Стародавній Греції.

Виклад основного матеріалу 3 повним обгрунтуванням отриманих наукових результатів. Розглянемо особливості системи освіти, що склалась у Стародавній Греції приблизно з V ст. до н.е. та проіснувала декілька сторіч (безумовно зі змінами та трансформаціями). Вона включала етапи, які б ми сьогодні назвали як початкова, середня та вища освіта (рис. 1).
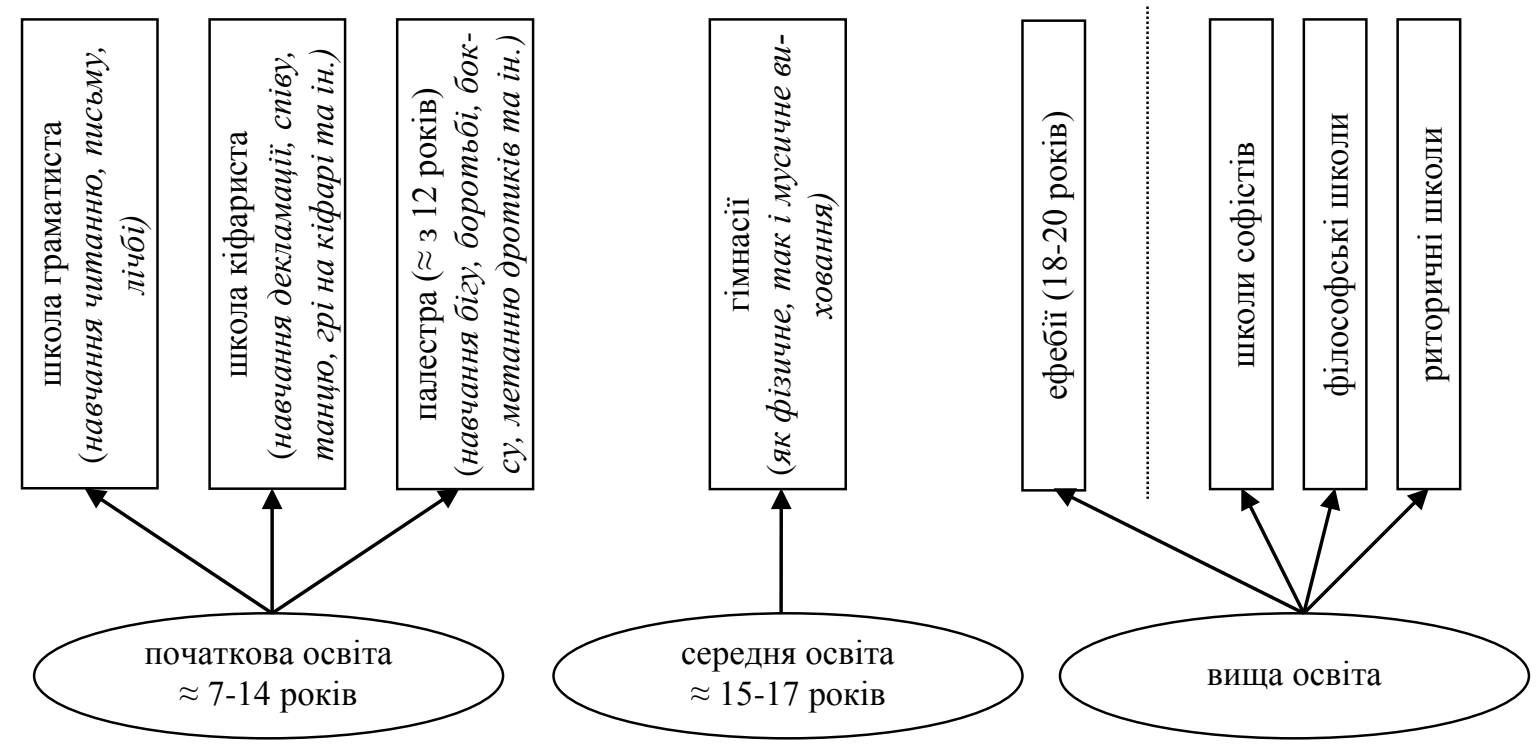

Рис. 1 - Освіта у Стародавній Греції

Початкова освіта дитини (власне тільки хлопчаків; дівчата переважно отримували домашню освіту) розпочиналась у сім років із навчання читанню, письму, лічбі. Того, хто навчав називали «граматист», «той, хто навчає буквам», «вчитель». Основним методом навчання було механічне запам'ятовування з голосу вчителя, повторення за вчителем. Проблеми розробки ефективної методики викладання залишались поза увагою вчителя, тому навчались початковій грамоті діти доволі довго й складно: потрібно було завчити на пам'ять алфавіт, потім усі мо- 
жливі склади 3 двох букв, потім 3 трьох (послідовність визначалась алфавітом відповідно до першої букви складу), потім переходили до запам'ятовування слів, і нарешті до читання та запам'ятовування вибраних уривків із класичних поетів. Викладацька майстерність була дуже низькою, адже поширеною суспільною думкою у Стародавній Греції було уявлення, що навчати елементарній грамоті може будь-яка людина, яка сама є грамотною. Для викладацької діяльності ніяких спеціальних знань та вмінь не потрібно, а якщо додати до цього низьку престижність професії граматиста у суспільстві (про нікудишню людину казали: «він помер або став вчителем»), то семирічний строк для вивчення елементарної грамоти грецькою дитиною вже не $\epsilon$ дивним.

А.-I. Марру наголошує на неефективності давньогрецької граматичної школи та іiі жорстокості, що лишається такою протягом століть: «у 234 році н. е. вважають ще цілком природним, що дитина дев'яти років не може написати свого імені (йдеться не про якогось невігласа: в сорок років ми застаємо ту ж саму особу комархом у своїй галузі). У 265 році ми зустрічаємо хлопців десяти-тринадцяти років, про яких нам повідомляють, що вони в даний момент «вчаться грамоті». Це перегукується з психологічною порочністю застосовуваних методів. Як в стародавніх школах Сходу, педагогіка залишилася рудиментарною: вчитель не вміє полегшити дитині доступ до знань; він не піднімається над рівнем пасивного навіювання тощо.Щоб перемогти те, що він вважає несприйнятністю до навчання, йому залишається тільки один засіб, перед яким він ні на хвилину не зупиняється: тілесні покарання» [9, с. 221].

Музиці та співу навчав вчитель «кіфарист» (для дітей 3 небагатих сімей часто «граматистом» та «кіфаристом» виступав один учитель), після 12 років для фізичного виховання дитина починала ходити до палестри (приватні гімнастичні школи), вчителя гімнастики називали «педотриб».

A.-I. Марру відзначає, що на другому (середньому) рівні освіти «наступником першого вчителя - граматиста

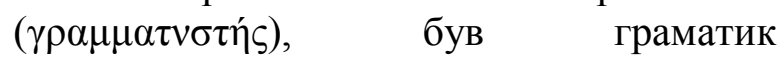
$(\gamma \rho \alpha \mu \mu \alpha \tau 1 \kappa o ́ \varsigma) »$ [9, с. 225], а зміст навчання був більш складним: вивчаються не тільки класичні твори поетів, що передбачало заучування, декламацію, пояснення смислу текстів, але й виконувались елементарні вправи на складання самостійних літературних творів, а в елліністичну епоху вивчаються початкові наукові знання з геометрії, арифметики, астрономії, музики.

Для нашого дослідження цікавим $€$ аналіз особливостей вищої освіти. 3 вісімнадцяти років вільнонароджений юнак мав право вступити до ефебії (як навчальний центр сформувалась приблизно в IV ст. до н.е.), і якщо початкова та середня освіта була переважно приватною та вимагала коштів від батьків дитини, то ефебія була на утриманні держави. Певний час ефебія була обов'язковою для юнаків та організовувалась як система військової освіти, після іiї закінчення юнак офіційно отримував повноправне громадянство. Але після завойовницьких війн Олександра Македонського та втрати грецькими полісами своєї незалежності, в ефебії змінився напрям освіти 3 військового на переважно мусичний. До афінської ефебії почали з'іжджатись іноземні студенти як до певного культурного освітнього осередку, а навчання стало дуже дорогим.

Особливими формами вищої освіти були софістична школа, філософська та риторична школа. Софістична школа (друга половина V ст. до н.е. - перша половина IV ст. до н.е.) була орієнтована на підготовку до політичної діяльності, участі в дискусіях, судових справах, суперечках. Навчання було платним, основним методом була лекція (за А.- I. Марру, софісти $\epsilon$ «зачинателями жанру лекції»). Учням також давались практичні вправи, щоб вони розвивали вміння переконувати та вміння говорити. При цьому не було 
важливим здійснювати пошук істини та раціональна аргументація, головне - перемога в суперечці, тому в учня розвивалось уміння переконувати як «за», так i «проти» одного й того ж твердження, застосовуючи хитрощі та маніпуляції.

Розвиток риторичних шкіл потрібно розглядати $з$ тієї школи, заснованої Ісократом у IV ст. до н.е. Хоча, як і в софістичній школі, Ісократ навчав красномовству, але на відміну від софістів значну увагу приділяв моральності: «майстерність мови, ісократівське красномовство, на відміну від софістичного, вже не безвідповідальною риторикою, байдужою до свого реального змісту» [9, c. 126].

Навчання учнів передбачало початковий теоретичний вступ, який Ісократ зводив до мінімуму, оскільки вважав, що основний наголос потрібно робити на практику. Практична спрямованість передбачала вивчення, обговорення, коментування кращих зразків промов, потім наслідування зразків, а пізніше - складання власних промов. Навчання відбувалось протягом 3-4 років й коштувало доволі дорого, викладацька діяльність Ісократа зробила його багатою людиною.

Риторичні школи були найбільш популярними в Стародавній Греції не тільки в класичну, але й в елліністичну епоху. На відміну від традицій давніх греків, нащадки особливу шану віддають філософським школам як інтелектуальним осередкам, що відіграли ключову роль у розвитку наукового мислення.

Найбільш видатними та відомими філософськими школами Стародавньої Греції є: Піфагорійський союз (заснована біля 532 р. до н.е. Піфагором, існувала до середини IV ст. до н.е.), Академія Платона (заснована у 388 р. до н.е. Платоном, існувала більше 900 років), Лікей Аристотеля, (заснована у 335 р. до н.е. Аристотелем, існувала більше 860 років), школа Епікура («Сад Епікура») (заснована близько 306 р. до н.е. Епікуром, існувала приблизно 900 років), школа стоїків (заснована близько
300 р. до н.е. Зеноном, існувала приблизно 500 років). Філософські ідеї кожної із цих шкіл не $є$ предметом нашого дослідження, зосередимо увагу на їх особливостях як освітніх осередків. При унікальності кожної школи, можна виділити декілька спільних рис:

- філософські школи - це більш або менш замкнуте товариство однодумців. Послідовники школи не тільки навчались, вони поділяли переконання, характерні відповідній школі, це було братство, членів якого пов'язували дружні стосунки;

- у школах давались філософські та наукові знання, але вони мали й релігійну складову. Зокрема, в Піфагорійському союзі, Академії, Лікеї існував культ Муз, а, наприклад, після смерті Платона в Академії був й культ «самого Платона, якого почитали як героя» [9, с. 102.];

- приєднання до школи - це не тільки можливість здобуття нового знання, це певний уклад життя. У більшості шкіл учнів відрізняв аскетичний спосіб життя у поведінці, одязі, їжі, певні морально-етичні правила. Наприклад, члени Піфагорійського союзу ходили у білому одязі, не їли м'яса, відмовлялись від вина, мали дотримуватися словесного «посту» $\mathrm{i}$ навіть повного мовчання, мали бути скромними, зневажати славу та багатство (до речі у цій школі відмовлялись від особистої власності, все було спільним) та ін. [15];

- передбачалось передусім вивчення філософських ідей засновника філософської школи. Хоча, окрім філософії, - могли вивчатись й інші дисципліни,: наприклад, в Лікеї Аристотеля історія, громадянське право, природознавство (біологія), риторика, література, мистецтво поезiї [14, с. 116];

- учні надзвичайно шанували своїх Вчителів;

- головою шкіл спочатку був засновник, а потім наступники, які продовжували традиції школи.

Методами навчання в філософських школах були лекції, коментування філософських текстів, дискусії, індиві 
дуальні бесіди. А.-І. Марру особливо наголошував на близько та особистісному впливі Вчителя-філософа як наставника на своїх учнів: «від філософа вимагалось бути не тільки викладачем, але також, і в основному, наставником, духовним керівником, справжнім розпорядником душі. Головне в такому навчанні не підносилося 3 висоти кафедри, а давалося в гущі повсякденного життя, яка об'єднувала філософа 3 його учнями. Більш, ніж слова, був важливий його життєвий приклад, повчальне видовище практичної мудрості і чесноти. Звідси та прихильність, часто дуже гаряча, яка пов'язує учня з наставником» $[9$, c. 292].

Як ми бачимо, викладацька майстерність на рівні вищої освіти була набагато більш розвиненою, ніж у елементарній школі. Причин цьому також декілька: видатні інтелектуали свого часу засновували філософський чи риторичний освітній осередок за власним бажанням, можна сказати, що це було покликання. Граматистом людина ставала через безвихідь, нездатність займатись ніякою іншою діяльністю, але необхідність заробляти на життя. Школу граматиста відвідувала кожна дитина чоловічої стати, це було обов'язковим (відомо, що для деяких полісів Стародавньої Греції загальна грамотність $є$ характерною вже з V ст. до н.е.). Вища освіта (окрім певного часу ефебіi) це був вільний вибір школи та вчителя. Не дивно, що саме тут розвивались нові методи навчання, софісти, ритори, філософи відзначалися красномовством та здатністю захоплювати своїх учнів. Конкуренція за учнів та «сила особистості», інтелектуальні здатності викладачів вищих шкіл у Греції були «двигуном» розвитку викладацької майстерності. Безумовно, постать філософів як керівників освітніх осередків це постать творця, чия діяльність надихала та викликала «гарячу прихильність» учнів.

Особливу цікавість Стародавня Греція викликає саме через бурхливий розвиток інтелектуально-творчої діяльності, який ознаменувався розквітом літератури, скульптури, архітектури, появою театру, й, що нам особливо цікаво, - виникненням філософії та науки. «Грецьке диво» настільки надзвичайний етап в історії, який $\epsilon$ початком, джерелом всієї західної культури. Але остаточної відповіді ще не знайдено, проблема залишається предметом постійних наукових дискусій. Безумовно, ми не можемо аналізувати детермінанти розвитку освіти в Стародавній Греції, не враховуючи загальний розквіт грецької культури й взаємовплив культури та освіти. У своєму аналізі ми спираємось як на історичні дослідження, так і на різноманітні уявлення вчених щодо причин «грецького дива».

Однією 3 передумов інтелектуального розквіту та становлення освіти можна вважати техніко-економічний прогрес та політичну експансію (VIII-VI ст. до н.е.). Початок I тисячоліття до н.е. ознаменувався поширенням заліза, що призвело до технічної революції, а, відповідно, й економічного підйому. 3 середини VIII ст.до н.е. розпочалась грецька колонізація, з VII ст. до н.е. - чеканка монет, перехід до грошового господарства, інтенсивно розвивається сільське і ремісниче виробництво та торгівля. Це, у свою чергу, сприяло особистісній активності та ініціативності, інтелектуальному розвитку, потребувало нових знань населення. А використання рабської праці разом із технічним прогресом зумовлювали появу вільного часу для громадян грецького полісу, який можна було використовувати для дозвілля, але й для інтелектуальних занять та творчості.

Політична експансія, розширення грецького світу, зовнішня торгівля сприяли знайомству греків 3 життям та звичаями інших народів та країн. Це означало «розширення розумового кругозору» (В.П. Бузескул), досягнення «небувалого раніше різноманіття умов існування і культурних контактів» (О.І. Зайцев). При цьому Г. Скирбекк та Н. Гильє зазначають, що при знайомстві з іншими культурами «протягом всіх часів найбільш по- 
ширеною реакцією було прагнення знищити «чужинців, які дотримуються жахливих звичаїв» й так не схожі на нас!» [14, c. 61]. Вони наголошують на унікальності грецької культури, наслідком чого були спроби осмислювати та обговорювати етико-політичні питання, замість знищення чужого й незвичного. Цінності грецької культури, які визначали спрямованість греків на пізнання, ми спробуємо проаналізувати пізніше.

Окрім інтенсифікації інтелектуальної діяльності, яка часто спостерігається в умовах техніко-економічного підйому, були й інші його наслідки. Зокрема, O.I. Зайцев відзначає, що існування невеликого міста-полісу з відносно невеликою кількістю населення, яке безпосередньо може брати участь у народних зборах (пряма демократія), тільки й могло існувати в умовах технічного прогресу [7]. В.П. Бузескул вказує на техніко-економічні передумови становлення демократії, в результаті чого з'явилась опозиція, розпочалась боротьба народу (демосу) проти аристократії, яка й закінчилась переходом до демократії [1].

Демократична форма правління в деяких полісах Греції, зокрема Афінах, розглядається значною кількістю науковців як важливий фактор культурної революції та розвитку науки. Аргументування цього таке [2; 13]: пряма форма демократії означала рівні права для кожного вільнонародженого громадянина чоловічої статі для безпосередньої участі у народних збоpax й, відповідно, управлінні містомдержавою - полісом. Реалізація свого громадянського права на участь у державній діяльності потребувала освіченості, володіння ораторським мистецтвом, умінням аргументувати, переконувати. Атмосфера обговорення, суперечки, публічного відстоювання своєї думки, боротьби 3 опонентом створювали особливий інтелектуальний умонастрій, який сприяв появі видатних мислителів, становленню системи освіти та загальній грамотності населення. Це пояснює й появу шкіл софістів, на зміну яким прийшли риторичні школи, й більшу популярність та поширеність риторичної освіти порівняно 3 філософською, й те, що саме риторику греки вважали «царицею всіх мистецтв», й те, що 3 двох опонентів - Платона та Ісократа, які жили та творили приблизно в один й той же час, саме Ісократ (як це не дивно для нас сьогодні) був більш популярним.

Але не всі погоджуються 3 думкою, що ключовим фактором культурного перевороту потрібно вважати демократію. Зокрема O.I. Зайцев вважає, що цю точку зору потрібно прийняти тільки 3 деякими застереженнями, а також наводить приклад Мілету, який став першим «вогнищем культурного перевороту» (зокрема основоположником науки вважається Фалес 3 Мілету), хоча управління здійснювалося тут не демократично.

Дійсно, вплив демократії на інтелектуальний розвиток не можна заперечувати, але не все було настільки однозначним, як це подається в деяких працях. Окрім мілетських філософів, які працювали при владі тиранів, можна розглянути й інші факти. Демократична форма правління закінчилась біля 338 р. до н.е., коли грецькі поліси опинилась під владою Македонії, але III ст. до н.е. та II ст. до н.е. (меншою мірою) подарували низку блискучих науковців (Аполлоній, Архімед, Евклід, Ератосфен, Гіппарх та ін.). Після 338 р. до н.е. як продовжують існувати освітянські інститути, так і триває бурхливий розвиток наукової думки.

В.П. Бузескул, вивчаючи історію афінської демократії, з однієї сторони вказує на загальну грамотність населення: «грамотність в Афінах була широко розповсюджена; майже кожен афінянин вмів читати і писати: у Арістофана у «Вершників» навіть ковбасник, вуличний торговець, грамотний: «наукам не вчений, лише грамоті», хоча «і тієї худого гірше»» [1, c. 212]. 3 іншого боку, частина демосу була малоосвіченою, «наукам не вчена». Більш того народна маса «сповнена була забобонів і упереджень; вона мало співчуває но 
вому просвітництву і швидше вороже налаштована щодо нього; вона, по суті, не терпить дослідників природи, бачить в них безбожників i шкідливих вільнодумців. Нарешті, в їі очах перевага розуму i освіти порушує до певної міри принцип рівності» [1, с. 213]. В.П. Бузескул наводить приклад промови демагога Клеона «який хвалить неосвіченість, знаходячи іiі кориснішою за розум та освіту для держави: «...простіші люди звичайно краще правлять державою, ніж розумні»» [1, с. 213]. Нижчі елементи демосу, які володіли тільки початковою грамотністю й були загалом малоосвічені, досить легко підпадають під маніпуляційні впливи демагогів та сикофантів. Криза демократії під час Пелопоннеської війни (431-404 рр. до н.е.) та її поступовий занепад протягом IV ст. до н.е., а також економічні проблеми, які викликає будь-яка війна, тільки загострили протиріччя у суспільстві.

Отже, демократія $\epsilon$ важливим, а можливо й ключовим фактором, для поширення загальної, початкової грамотності населення Греції, з іншої сторони, при всіх іï перевагах, були й «темні сторони демократії» (В.П. Бузескул), мали місце софістика, демагогія, маніпуляції; владою володіли й малоосвічені, без критичного мислення, «не мудрі» демос, тож про розвиток «раціонального умонастрою» (Ж.-П. Вернан) можна говорити тільки 3 деякими застереженнями. Не дивно, що низка філософів того часу аналізує різні сторони, у тому числі негативні, демократичної форми правління (Геродот, Аристотель та ін.), з жорсткою критикою демократії виступає Платон.

У той же час, демократична форма правління була безпрецедентним феноменом для свого часу. В. Дюрант зазначає, що хоча у IV ст. до н.е. народні збори «виродилися в збори натовпу, що ненавидить будь-яке переважання», але «хіба олігархія або монархія були б краще? За кілька місяців свого правління Тридцять тиранів зробили більше злочинів проти особистості і власності, ніж демократія за попередні сто років... Грецька демократія

- корумпована і невміла - була приречена на загибель. Але коли вона померла, люди усвідомили, яким прекрасним був іiі розквіт» $[6$, с. 559].

Інтелектуальна еліта - це завжди відносно невеликий прошарок суспільства, але в умовах загальної, хай й тільки початкової освіченості, в умовах, коли кожен громадянин мав ходити до школи, бути охопленим системою грецької освіти, коли існували різноманітні освітянські інститути, справжньому таланту, що має потяг та здібності до пізнання, до науки, легше розвинути свої здібності та досягти певних вершин у своїй творчості.

Сам уклад життя вимагав освіченості та знань від громадян грецьких полісів й одночасно сприяв їм. Окрім розповсюдженості занять політичною діяльністю, були й інші звичаї. Важливою частиною життя греків були бенкети - i це була не тільки пиятика, але й філософські та літературні діалоги, читання напам'ять творів класичних поетів та проголошення віршів власного творення. П. Волкова наголошує, що традиція грецьких бенкетів унікальна й існувала тільки в Античності, а в умовах, коли існувала традиція вести філософські бесіди, «діалоги про головне», як раз й можливе народження видатних філософів [4].

Релігійні обряди вимагали вміння грати на кіфарі, співати та танцювати, тобто отримувати освіту у кіфариста; спортивні змагання, зокрема Олімпійські, Піфійські та Німійські ігри, необхідність брати участь у війнах та захисті полісу вимагали навчання у палестрах, гімнасіях, ефебіях. До речі, П. Волкова вважає ефебії - тим фактором, що (при відсутності загальних кордонів) визначали Елладу: якщо у місті була ефебія (або їі аналог), де відбувалась у тому числі фізична підготовка, й випускники якої мали можливість брати участь у Олімпійських іграх, то це місто належало до Еллади [4]. Тобто освітні інститути виступали одним із факторів еллінського самовизначення. 
Усталений побут греків, як і загальна атмосфера, характерна для культурного перевороту, впливали на освіченість та розвиток громадян грецьких полісів: «розвиток мистецтва і літератури, театр, - все це повинно було діяти розвиваючим чином і піднімати загальний рівень» $[1$, с. 213$]$.

Техніко-економічний прогрес та політична експансія, демократична форма правління, уклад життя є зовнішніми чинниками розвитку освіти у Стародавній Греції, вважаємо необхідним перейти до розгляду внутрішніх чинників - ідеалів, цінностей, уявлень античних греків.

Гомеровський епос є етичним ідеалом для Еллади: бажання бути першим, найкращим, видатним, неперевершеним, справжнім героєм, схильність до змагань та жага до перемоги у змаганнях - цінності та ідеали, які відрізняють героїв поем Гомера і які стали керівними принципами для греків. Платон у своїй праці «Держава» зазначає, що «Гомер виховав Грецію». Можна вважати показовим й те, що Олександр Македонський брав 3 собою «Іліаду» у походи.

Поеми Гомера були «книгою життя», кодексом правил та моральноетичних норм, ідеальним орієнтиром, до якого прагнув кожен грек. Їх вивчали, обговорювали, коментували на всіх рівнях освіти, давні греки знали їх напам'ять та цитували у промовах, у виступах на бенкетах тощо.

Але окрім того, що зміст гомеровського епосу виступав керівним орієнтиром, в ньому містився й виховний потенціал іншого плану: формування уявлення про те, що джерелом мудрості $\epsilon$ знання, які можна почерпнути у літературному творі, тому важливим $\epsilon$ їх вивчення, засвоєння культурних зразків підростаючим поколінням. З'являється те, що В. Петров називає «книжна культура» [12].

На морально-етичні норми накладало свій відбиток й те, що для життя Стародавньої Греції характерною була культура закритого чоловічого клубу. Жі- нки в Елладі майже не допускались до суспільного життя: практично весь час вони проводили вдома: до заміжжя у домі батька, після - у домі чоловіка. Народні збори, суди, спортивні змагання - до них не допускались жінки, майже всі події, більшу частину свого життя кожен чоловік Стародавньої Греції проводив серед інших чоловіків, коло спілкування практично виключало жінок. Безумовно, це відбивалось у суспільних нормах та особливостях освіти. Розповсюдженою традицією було наставництво: утворення пар старший чоловік та молодший юнак, в якій перший був взірцем, навчав, передавав досвід, піклувався про молодшого, у свою чергу «юнак відповідав йому повагою i прагненням бути гідним цієї турботи. Між ними траплялося різне, в тому числі виникали любовні зв'язки» [12]. А.-I. Марру підкреслює утворення таких пар: «учитель зі своєї висоти звертався до того, кого вважав гідним. Довгий час античність буде зневажати викладача, який заводить лавочку і пропонує свої пізнання випадковому покупцеві: знання має повідомлятися лише тому, хто заслужив» [9, с. 57].

3 такої традиції походить ставлення до передачі знань у філософських школах, як до таїнства, в яке можуть бути посвячені тільки обрані, так і ставлення до учителя 3 особливою прихильністю, та відданістю. Починаючи з ефебії, вчителя та учня може поєднувати тісний зв'язок, духовна близькість, а часто й любовні стосунки. Такі стосунки засуджувались би у нашому сучасному суспільстві, але потрібно пам'ятати, що не можна оцінювати традиції минулого з позицій сьогоднішнього дня, оскільки кожен народ у ту чи іншу епоху проживає життя відповідно до власної культури та власних цінностей.

Незвичайним же для традицій давності були особистісні свободи як характерна особливість саме Стародавньої Греціï. O.І. Зайцев вважає, що «нечуване ніде раніше розширення особистісних свобод» $\epsilon$ більш значущім фактором культурного перевороту, ніж економічний прогрес та 
демократія. При цьому він наголошує: «під свободою тут треба мати на увазі свободу не тільки від надмірного втручання держави, а й свободу від часто неписаних традицій, які можуть підкоряти собі життя людини не менш ефективно, ніж спартанська держава» [7, с. 260]. Безумовно особистісні свободи у Стародавній Греції не можна порівнювати зі свободами, які стануть здобутками європейської культури багато століть потому, але порівняно $з$ дописьменними державами та державами Стародавнього Сходу, Греція зробила «величезний шаг уперед». O.I. Зайцев вказує на зміни традиційних, родових норм життя та відкритості Еллади до всього нового, свободу пересування, ослаблення впливу релігії, свободу обирати спосіб життя та свободу в мистецтві. Зокрема, грецьке мистецтво було досить вільним у зображенні богів на відміну від мистецтва країн Сходу [7]. Існувала у Греції й свобода слова, як зазначає К. Куле, «свобода слова здійснювалася в дуже широких межах і стосувалася перш за все комедії. Там критика і політична сатира були справою звичною» [8, с. 141].

Умови особистісної свободи надзвичайно сприяють розвитку освіти та інтелектуальній творчості. Поява різноманітних філософських та риторичних шкіл, боротьба думок, вільне висловлювання своїх поглядів та дискусії, можливість вільного вибору вчителя та відповідної школи для вищої освіти - всі ці фактори $є$ визначальними для освіти Греції. Особистісні свободи зумовлюють й свободу думки, свободу самовираження та свободу розвитку здібностей людини. В Дюрант вказує, що свобода була «кумиром» для Греції, і що «тільки це почуття громадянської індивідуальності, ця завзятість в незалежності, що б'є через край, ця різноманітність настанов, звичаїв, мистецтв і богів спонукало Грецію жити, змагаючись і конкуруючи, життям, відміченим жаром, повнотою і творчою самобутністю, яких не знало раніше жодне суспільство» [6, с. 239].
Особливо яскравою рисою гре-

цьких полісів була спрага до змагань, агоністичний дух грецької культури. Змагання були характерними вже для архаїчної епохи, вони проводились як у сільськогосподарській діяльності, так і серед ремісників, але найбільшою мірою були розповсюджені атлетичні, та дещо пізніше мусичні змагання. Серед атлетичних змагань найбільш престижними були Олімпійські ігри (виникли в 776 р. до н.е.), перемога в яких уявлялась як найбільше благо та була, за висловом П. Волкової, «шляхом до безсмертя», тим, що наближає людину до богів [4]. У той же час поступово все більше вкорінюються уявлення, що не тільки військові та спортивні, але й будь-які досягнення заслуговують пошани та слави. Стосовно мусичних змагань, то вони були дуже різноманітними та присвяченими музиці, поезії, співам, танцям, красномовству.

Такі змагання мали двоякий вплив на розвиток освіти: по-перше, для того, щоб в них брали участь потрібно мати відповідну підготовку та розвивати свої таланти; по-друге, змагання влаштовувались на всіх рівнях освіти, починаючи 3 початкової, a, отже, їх можна розглядати як стимулюючий фактор та метод навчання. В. Петров зазначає: «учні змагалися, хто швидше опанує алфавіт, хто краще читає, рахує, співає, танцює, грає на лірі, хто є вправнішим в словесній суперечці, хто більше пам'ятає віршів Гомера, хто сильніший в мелодекламації, хто вправніше в боротьбі, хто швидше біжить, далі стрибає, довше тримається без повітря під водою, більше піднімає, точніше метає спис або диск і т.ін. Ці змагання ... були відображенням загального для всіх греків прагнення мірятися силами в чому завгодно, як і коли завгодно» [12].

Інтелектуальні суперечки також були пронизані агональним духом та сприяли пошуку істини: «агон дав філоcoфiї і науці діалог як «методичний шлях пізнання»»» [7, с. 119]. О.І. Зайцев вважає агоністичну установку також одним із ва 
жливих факторів «грецького дива», але, як і особисту свободу, - не визначальним. Агоністика виникає як поєднання потреби у грі та честолюбства, прагнення успіху [7, с. 122]. I ключовим фактором культурного перевороту, з точки зору О.I. Зайцева, є саме прагнення успіху, бажання бути першим та найкращим.

Він зазначає, що самовихваляння було природним для греків: «живописець Паррасий одягався в пурпур та золото i сам прославляв себе в віршах як першого грецького художника, який досяг меж досконалості в мистецтві, як сина Аполлона. Свій автопортрет він наділив написом «Бог Гермес»... Навіть вправний майстер килимових справ міг, присвятивши килим в Дельфи, стверджувати, що сама Афіна допомогла йому в роботі» [7, с. 119]. Греки, керуючись потягом до слави, не тільки вихваляли свої досягнення та переваги, але й насміхались із поразок та невдач інших. I такі насмішки могли призвести навіть до самогубства [7], настільки це було нестерпним у суспільстві, де панував культ успіху та слави.

А.-I. Марру наголошує на гордині як визначальній якості греків, як риси, що вважається прийнятною та природною i що виступає в протиріччя із християнськими заповідями. Про мораль грека він пише «сяяти, бути першим, перемогти, восторжествувати, затвердити себе в змаганні, перевершити суперника перед суд-

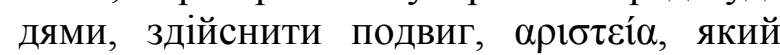
зробить його першим серед людей - сучасників, а може бути, і нащадків - ось навіщо він живе і для чого він помирає. Така мораль честі, багато в чому далека від християнської душі. Вона передбачає прийняття гордині, $\mu \varepsilon \gamma \alpha \lambda о \psi v \chi і ́ \alpha$, яка не порок, а піднесене прагнення до великого» $[9$, с. 32].

У той же час, O.I. Зайцев робить уточнення щодо мотивації до успіху, 3 його точки зору ключовим фактором «грецького дива» потрібно вважати передусім «обмежено-прагматичний оптимізм», тобто світосприйняття, яке за- сноване на вірі у свої сили, на позитивному ставленні до власних зусиль, на спроможності вирішити повсякденні завдання та проблеми, така віра $є$ джерелом «підйому діяльнісної енергії» у суспільствi [7].

Ми ж вважаємо необхідним наголосити на пошані до інтелектуальних успіхів: славу приносили не тільки перемоги у спортивних змаганнях, у військових баталіях або у судах, почесними були здобутки у різних сферах. Митець, філософ, науковець, ритор прагнули бути найкращими, першими, відомими. Культ Піфагора та Платона, про який ми вже писали, чудово ілюструють грецькі традиції. Філософи та науковці отримували повагу та славу за свої досягнення, й такі звичаї, таке ставлення також було двигуном інтелектуального та освітнього розвитку.

Загалом розвиток раціонального мислення та науки вважаємо одним із найбільш важливих факторів формування освіти Стародавньої Греції, оскільки фізичні, етичні, математичні, політичні, медичні та інші теорії можуть вивчатись молоддю та дорослими, збагачують систему освіти та сприяють подальшому руху інтелектуальної думки.

В. Дюрант перелічує декілька досягнень натурфілософів: «у Акраганті Емпедокл висунув ідею, що для проходження $з$ однієї точки в іншу світлу потрібен час. В Еліi Парменід проголосив, що Земля має кулеподібну форму, розділив планету на п'ять поясів і зауважив, що освітлена сторона Місяця завжди повернена до Сонця. У Фівах піфагорієць Филолай змістив Землю з центру Всесвіту і звів її до статусу однієї з багатьох планет, що обертаються навколо «серединного вогню»»» [6, с. 347-348]. Зазначає, що досягнення Анаксагора зробили його «одночасно Коперником та Дарвіном свого часу» [6, с. 349], підкреслює, що «історична роль Гіппократа i його наступників полягала у звільненні медицини як від релігії, так і від філософії», Гіппократ «прямо нападає на теорію, за якою хвороби 
викликаються богами; всі хвороби... мають природні причини» [6, с. 352]. Це тільки деякі приклади, загалом VI-II ст. до н.е. подарували світові цілу низку блискучих імен.

Проте, безумовно, не можна казати, що Стародавня Греція пережила однозначний та цілковитий поворот від релігії до науки. Міфологічне мислення, забобони, релігійні вірування нікуди не зникали й антагонізм цих двох течій продовжувався у тому числі у століття найбільшого розквіту раціональності у Греції.

Малоосвічений демос, як вже відзначалось, з підозрою ставився до діяльності інтелектуальної еліти і демократичні процедури іноді сприяли реакційним проявам. Так, В. Дюрант вказує, що «складовою частиною боротьби між релігією і наукою була заборона на заняття астрономією, накладена афінським законодавством в самий розпал Періклової епохи» [6, с. 347]. Широковідомим є процес над Сократом (399 р. до н.е.), якого звинувачували у «запереченні богів, які визнає місто, $\mathrm{i}$ у введенні нових божественних істот», а також у «розбещенні молоді» [10, с. 104]. Але були й інші процеси звинувачення у безбожності - проти Анаксагора, Фідія, Аспасії, Протагора, Діагора та Андокіда (друга половина V ст. до н.е.) [11]. При цьому, О.В. Нікітюк зазначає, що ці процеси мали політичне й особистісне підгрунтя та були відносно рідкими, загалом зберігалась атмосфера віротерпимості [11].

Отже, особистісні свободи в Стародавній Греції не можна вважати беззаперечними, як ми бачимо, були й реакційні процеси, проте в цілому, порівняно з минулими століттями та майбутнім середньовіччям, в ній здебільшого існувала свобода думки та свобода творчості, що сприяло становленню та розвитку раціонального мислення та впливало на різноманітність, глибину та науковість грецької освіти.

Розповсюдженість переконання про цінність освіти особливим чином впливала як на загальне поширення початкової освіти вільнонароджених гро- мадян Греції чоловічої статі, так і на появу інститутів вищої освіти, що саме по собі є революційним для стародавніх часів. Софісти, ритори, філософи були опонентами щодо уявлень про те, як треба навчати та щодо практичної організації навчання в своїх школах, але вони забезпечували різноманітність можливостей поглибленої освіти для юнацтва та дорослих греків. Потрібно наголосити, що бурхливо розвивалась не тільки практика, але й теорія освіти. Розроблялись перші теоретичні концепції ідеальної освіти, в яких мислителі особливо наголошували на іiі важливості. Зокрема, Аристотель вважав, що освічена людина перевершує невігласа настільки «наскільки живі перевершують мертвих» [6, с. 298]. Ісократ зазначав, що «ми називаємо еллінами тих, 3 ким нас об'єднує культура скоріше, ніж просто людей однієї з нами крові» [9, с. 129], тобто освіта та культура виступали засобом самоідентифікації греків. В умовах полісної суспільної організації, при відсутності єдиної держави 3 певною територією та кордонами, освіта була одним із об'єднуючих факторів, тим, що відрізняє елліна від представника інших народів, «варварів».

О.Н. Джуринський відзначає, що в Греції «відсутність можливості отримати освіту розглядалося як одне 3 найгірших вад. Саме тому, як стверджує давньогрецький історик Плутарх, переможці з міста Мілет покарали дітей переможених забороною вчитися грамоті й музиці» [5, с. 18].

Але ідеалом Стародавньої Греції була не просто освічена особистість, а різнобічна освічена особистість. Як відзначає Л. Вінничук, «виховання розумілося як нерозривна єдність «гімнастичного» $\mathrm{i}$ «мусичного», як розвиток фізичний i розумовий одночасно. Синтезом цих двох елементів мало стати класична рівновага тіла і духу, прославлений ідеал «калокагатії» - краси і добра, злитих у людині воєдино» [3, с. 194]. Ідеал «калокагатії» означав єдність фізичної краси та моральної чесноти та розглядався як основна ме 
та освіти, як те, до чого має прагнути будь-яка людина. Пайдейа - це шлях до інтелектуальної, фізичної та моральної довершеності, сам термін «пайдейа» є визначальним саме для Античності, і означав він не просто освіту, але прилучення до культури, різностороннє становлення та розвиток особистості.

А.-I. Марру виступає опонентом досить поширеної точки зору відносно ідеалу гармонічного поєднання інтелектуального та фізичного розвитку в Стародавній Греції. Він вважає, що більшою мірою це $\epsilon$ «міф» $\mathrm{i}$, якщо й існував такий ідеал, то тільки «коротку мить», а загалом досвід свідчить, що ці дві тенденції можуть лише пригнічувати одна одну, а не існувати у цілісності та єдності [9]. Ми не можемо погодитись 3 такою думкою, адже, якщо колись й існував ідеал, який передбачав максимальну увагу до різносторонньої освіти та до різностороннього розвитку людини, то це було саме в Античності. Про це свідчать й переконання та звичаї, що панували у Стародавній Греції, й поширена практика освіти дітей та юнацтва (рис. 1). Якщо у Греції хотіли сказати про людину, що вона ні на що не здатна, то казали: «він не вміє ні читати, ні плавати». Навіть у цьому відомому вислові відображено необхідність для людини цілісної освіти: й граматичної, й фізичної.

Давньогрецькі мислителі можуть представляти для нас приклад гармонійної особистості. Наприклад, Піфагор, Демокріт, Гіппократ, Платон відомі, передусім, як видатні філософи, але вони були й переможцями та учасниками Олімпійських ігор, отже, це не тільки інтелектуальні генії, але й гарно фізично розвинені люди.

\section{Список літератури}

1. Бузескул, В. П. (2003) История афинской демократии. СПб.: ИЦ «Гуманитарная Академия», 480 с.

2. Вернан, Ж. П. (1988) Происхождение древнегреческой мысли. М.: Прогресс, 224 с.
Ми можемо тільки шкодувати, що деякі давньогрецькі звичаї канули в Лету. Ідеал загальної освіти буде втрачений на довгі часи, й почне поступове відродження у західних країнах тільки з XIX ст., ідеал гармонійної освіти - лишається недосяжним ідеалом й сьогодні.

Висновок 3 даного дослідження та перспективи подальших розвідок у даному напрямку. Таким чином, система освіти Стародавньої Греції передбачала початкову, середню та вищу освіту, остання була представлена такими освітніми інститутами, як ефебії, софістичні, риторичні та філософські школи. Викладацька майстерність була низькою для елементарної освіти, але на рівні вищої активно розвивається як викладацька практика, так і педагогічна теорія. Зовнішніми чинниками розвитку освіти та викладацької майстерності у Стародавній Греції є техніко-економічний прогрес та політична експансія, демократична форма правління, уклад життя, який вимагав різносторонньої освіченості. Внутрішніми (норми та цінності): гомеровський епос як етичний ідеал, що «виховав Грецію», культура закритого чоловічого клубу, поширеність особистісних свобод, агоністичний дух суспільства, культ успіху та слави, розвиток раціонального мислення та науки, розповсюдженість переконання про цінність освіти, ідеал різносторонньо освіченої особистості. На нашу думку, перспективними напрямами удосконалення сучасної освіти та викладацької майстерності в Україні може бути пов'язано з розвитком агоністики, мотивації успіху, підвищенням усвідомлення цінності гармонійної освіченості.

3. Винничук, Л. (1988) Люди, нравы и обычаи Древней Греции и Рима. М.: Высшая школа, 496 с.

4. Волкова, П. (2013) Мост через бездну. М.: Зебра, 256 с.

5. Джуринский, А. Н. (2000) История педагогики. М.: Гуманит. изд. центр ВЛАДОС, 432 с. 
6. Дюрант, В. (1997) Жизнь Греции. М.: КРОН-ПРЕСС, 704 с.

7. Зайцев, А. И. (2000) Культурный переворот в Древней Греции VIII-V вв. до н. э. СПб.: Филологический факультет СПбГУ, 320 с.

8. Куле, К. (2004) СМИ в Древней Греции: сочинения, речи, разыскания, путешествия. М.: Новое литературное обозрение, $256 \mathrm{c.}$

9. Марру, А. И. (1998) История воспитания в античности (Греция). М.: Греко-латинский кабинет Ю.А. Шичалина, 427 с.

10. Нерсесянц, В. С. (1977) Сократ. М.: Наука, 152 с.

11. Никитюк, Е. В. (1998) Процессы по обвинению в нечестии (асебии) в Афинах в последнюю четверть V в. до н.э. Античный мир: Проблемы истории и культуры. СПб.: Изд-во СПбГУ. С. 117 138.

12. Петров, В. (2011) Всякий, даровитый или бездарный, должен учиться... Как воспитывали детей в Древней Греции. М.: Ломоносов, 240 с. [Электронный ресурс] Режим доступа: https://history.wikireading.ru/356637

13. Рожанский, И. Д. (1980) Античная наука. М.: Наука, 198 с.

14. Скирбекк, Г. \& Гилье, Н. (2000) История философии. М.: Гуманит.издание ВЛАДОС, $800 \mathrm{c.}$

15. Суриков, И. Е. (2013) Пифагор. М.: Молодая гвардия, 269 с.

16. Tuplin, C. (2018). Xenophon, Isocrates and the Achaemenid empire: history, pedagogy and the Persian solution to Greek problems. Trends in Classics. 10(1). 13 - 55. doi: $10.1515 / \mathrm{tc}-2018-0002$

\section{References}

1. Buzeskul, V. P. (2003) Istorija afinskoj demokratii. [The history of Athenian democracy]. SPb.: IC «Gumanitarnaja Akademija», 480 p. [in Russian]

2. Vernan, Zh.-P. (1988) Proishozhdenie drevnegrecheskoj mysli. [The origin of ancient Greek thought]. M.: Progress, 224 p. [in Russian]
3. Vinnichuk, L. (1988) Ljudi, nravy $i$ obychai Drevnej Grecii $i$ Rima. [People, manners and customs of ancient Greece and Rome]. M.: Vysshaja shkola, 496 p. [in Russian]

4. Volkova, P. (2013) Most cherez bezdnu. [Bridge over the abyss]. M.: Zebra, 256 p. [in Russian]

5. Dzhurinskij, A. N. (2000) Istorija pedagogiki. [History of Pedagogy]. M.: Gumanit. izd. centr VLADOS, 432 p. [in Russian]

6. Djurant, V. (1997) Zhizn' Grecii. [Greece life]. M.: KRON-PRESS, 704 p. [in Russian]

7. Zajcev, A. I. (2000) Kul'turnyj perevorot v Drevnej Grecii VIII-V vv. do $n$. je. [Cultural coup in ancient Greece, VIII-V centuries. BC e.]. SPb.: Filologicheskij fakul'tet SPbGU, 320 p. [in Russian]

8. Kule, K. (2004) SMI v Drevnej Grecii: sochinenija, rechi, razyskanija, puteshestvija. [Mass media in ancient Greece: compositions, speeches, searches, travels]. M.: Novoe literaturnoe obozrenie, 256 p. [in Russian]

9. Marru, A. I. (1998) Istorija vospitanija $v$ antichnosti (Grecija). [History of education in antiquity (Greece)]. M.: Grekolatinskij kabinet Ju.A. Shichalina, 427 p. [in Russian]

10. Nersesjanc, V. S. (1977) Sokrat. [Socrates]. M.: Nauka, 152 p. [in Russian]

11. Nikitjuk, E. V. (1998) Processy po obvineniju $v$ nechestii (asebii) $v$ Afinah $v$ poslednjuju chetvert' $V v$. do n.je. [The trials of dishonest charges (asebia) in Athens in the last quarter of the 5th century. BC.]. Antichnyj mir : Problemy istorii i kul'tury. SPb.: Izd-vo SPbGU. P. 117 - 138. [in Russian]

12. Petrov, V. (2011) Vsjakij, darovityj ili bezdarnyj, dolzhen uchit'sja... Kak vospityvali detej v Drevnej Grecii. [Everyone, gifted or talentless, should learn ... How children were raised in ancient Greece]. M.: Lomonosov, 240 p. Access mode: https://history.wikireading.ru/356637 [in Russian] 
13. Rozhanskij, I. D. (1980) Antichnaja nauka. [Ancient science]. M.: Nauka, 198 p. [in Russian]

14. Skirbekk, G. \& Gil'e, N. (2000) Istorija filosofii. [History of philosophy]. M.: Gumanit.izdanie VLADOS, 800 p. [in Russian]
15. Surikov, I. E. (2013) Pifagor. [Pythagoras]. M.: Molodaja gvardija, 269 p. [in Russian]

16. Tuplin, C. (2018). Xenophon, Isocrates and the Achaemenid empire: history, pedagogy and the Persian solution to Greek problems. Trends in Classics. 10(1). 13-55. doi: 10.1515/tc-2018-0002

Стаття надійшла до редколегії 10.02.2019 